\title{
Effect of Chief Executive Officer's Characteristics on Capital Structure of Publicly Listed Firms in Kenya
}

\author{
Tecla Kosgei Mutai \\ School of Business and Economics, Moi University, Kenya \\ Daniel Kipkirong Tarus \\ School of Business and Economics, Moi University, Kenya \\ Joyce komen \\ School of Business and Economics, Moi University, Kenya \\ Kimutai Kevin Torois \\ School of Business and Economics, Moi University, Kenya
}

\begin{abstract}
Based on a panel of publicly listed firms in Kenya over the period of 2008 to 2014, we examined if Chief Executive Officer's Characteristics affects capital structure. CEO tenure, CEO gender and CEO age and CEO education were used as independent variables while the capital structure was used as the dependent variable of the study. The study used upper echelon theory, trade-off theory and agency theory. Majorly, descriptive statistics, Pearson correlation analysis and panel regressions were performed. Panel regression analysis was used to determine the effect of CEO characteristics on capital structure. CEO tenure had a negative and significant effect on capital structure, CEO age had a positive and significant effect on the capital structure, CEO gender and CEO education indicated a negative and significant effect on capital structure respectively. The study indicates that there is an association between CEO characteristics and capital structure of listed firms in Kenya. It is therefore instrumental for firms to appoint their CEOs based on the duration they have served the company, CEOs to sit in their position for a longer period of time and those who have the requisite knowledge and experience hence they can be tasked with making important decisions pertaining firms' financing.
\end{abstract}

Keywords: capital structure, CEO characteristics, Upper Echelon Theory, Trade-Off Theory, panel data and Agency Theory

DOI: $10.7176 /$ RJFA/11-18-07

Publication date:September $30^{\text {th }} 2020$

\subsection{Introduction}

The capital structure framework has been studied for a long time with no satisfactory theoretical model or significant empirical tests (Harris and Raviv 1991, Frank and Goyal 2008 Bae, et al., 2011). Enormous academic effort has gone into identifying the relevant factors associated with the debt-equity choice but still remains a puzzle in the sense that financial theories have unable to ccurately describe firms' behavior (Malmendier, 2018). To date, a theoretical explanation is still lacking and empirical results are not yet sufficiently consistent to resolve the capital structure issues on how firms choose between the different methods of financing. Indeed, several theories have been proposed to offer different explanations of capital structure since the publication of the seminal paper of Modigliani and Miller (1958). Modigliani-Miller (MM) propagated that the choice between debt and equity financing has no material effect on the firm value and consequently management should not be concerned about the proportion of debt and equity that constitute the capital structure of the firm. Various capital structure theories have been developed during the last 62 years in order to determine the determinants and financing mix used by corporations to finance investments, however there is no universal determinants and the theory of the debt-equity choice (Saona et al., 2018). Outstanding empirical and theoretical work in the field of capital structure has been done using several explanatory variables to explain capital structure. For example, Modigliani and Miller (1963) added the effect of corporate taxes to the capital structure framework Modigliani and Miller (1958) and found that firm value is maximized when the firm is financed entirely with debt which is of course impracticable because some ownership equity must exist in a firm. Since then, theories of capital structure have been developed to determine whether it plays a key role in the financing activity. For instance, debt and taxes (Miller, 1977), bankruptcy costs (Stiglitz, 1972; Titman, 1984), agency costs (Jensen and Meckling, 1976; Myers, 1977), information asymmetries (Myers and Majluf, 1984; Myers, 1984), firm level determinants, (Rajan and Zingales , 1995), industry-level determinants ( Lööf, 2004; Titman and Wessels, 1988) showed contradicting point of view in describing the impact of particular factor on capital structure.

There is a large body of work arguing that a firm's capital structure is influenced by managerial disposition (Bancel and Mittoo, 2004; Majumdar \& Chhibber, 1999; Barton \& Gordon, 1988). Artikis et al., 2007 \& and 
Downar \& Keiling, 2019). More importantly, studies have emphasized that managers make financing decisions by trading off the tax benefits of debt against the total cost of debt, where the latter includes the cost of financial distress and the cost of disciplining managers (Xu, 2012). To mitigate potential conflicts of interest, researchers have suggested that there is a need for the proper monitoring of managerial actions (Jensen and Meckling, 1976; Fama, 1980; Gottardo and Maria Moisello, 2014; Teece, 2019)

According to Cytonn Investment Report, 2016 Kenyan investors have incurred losses as a result of isolated corporate governance issues affecting over 13 per cent of listed firms. According to the report, some of the firms have accumulated massive debts that have pushed their management into a survival dogfight, exposing the perils of credit-fuelled expansion in tough economic times. The huge debts, which have left some of the firms owing more than their net value, have left investors facing low prospective returns for years to come. Currently these firms seek new cash injections to partly retire their loans and finance ambitious turnaround plans. This is worrisomely and intriguing, thence calling into question on whether the corporate governance structure and capital structure matter for the performance of publicly listed firms in a developed country like Kenya.

although Kenya and other emerging market have made significance corporate governance strides over the past decade, the adoptions and revisions of governance codes and relevant regulations have led to better disclosure standards, higher levels of board independence, and more shareholder protections (Oduor \& Kebba, 2019;). However corporate governance in publicly listed firms in emerging market like Kenya is still characterized by weak corporate board in relation to homogeneity, societal culture, and board structure and board selection (Katmon et al., 2019). For example, in the past few years, there have been a number of corporate failures occasioned by financial distress among listed firms. Notable cases of corporate failure include Uchumi Supermarkets, in 2006, and CMC Kenya Ltd., in 2012. The main reasons attributed to these corporate failures are their inefficient boards and the use of debt in the capital structure (Waweru and Prot, 2018). Although Kenya Capital Authority has enacted and implemented the corporate governance guidelines, there remains a need to determine whether governance mechanisms enhance effective decision making in Kenya, particularly with regard to capital structure.

Boards of directors consist of teams of individuals who combine competencies and capabilities that collectively represent the firm's pool of capital (Ujunwa, 2012). In a dynamic environment, board of directors is crucial to the smooth functioning of a company. Predominantly, boards of directors are responsible for monitoring managerial actions by approving major strategic and financial decisions, such as capital structure (Ujunwa, 2012).

Corporate boards have long been a subject of research in a variety of disciplines (Blake, 2016; Dallas, 2001; Jensen and Zajac, 2004). However, there is little consensus as to what a board should look like or even what kinds of people make the best board members (Sonnenfeld, 2002; Wodak et al., 2011). According to Hambrick and Mason (1984) through the upper echelons theory argued that organizational outcomes are related to the particular demographic characteristics of top level decision-makers.

Studies grounded in upper echelons theory contend that demographic characteristics such as age (Wiersema and Bantel, 1992), tenure (Hambrick et al., 1993), experience (Kroll et al., 2008) educational level (Wiersema and Bantel, 1992), functional background (Datta and Rajagopalan, 1998), gender and ethnicity (Carter et al., 2010) are important proxies for cognitive bias, and that these characteristics have an impact upon the ability to make decisions that enhance firm performance. According to upper echelons theory, CEO characteristics manifest in firm strategic actions, which in turn shape future firm performance. On the basis of these theoretical arguments by Hambrick and Mason (1984), we build our study to determine effect of CEO characteristics on capital structure of publicly listed firms in, Kenya.

Grounded on agency theory, Tarus and Ayabei, (2015) and Alves et al., (2015) carried out a study on relationship between Board composition and capital structure and found out that that board composition has important implications on capital structure decisions. Otherwise studies remain largely unknown especially in terms of the relationship between CEO characteristics and financial leverage (Ting et al., 2015).

The study was carried out in selected listed firms in the Nairobi Security Exchange in Nairobi City, Kenya. There is close to 64 listed firms in Kenya, however, the study focused on 37 listed firms which had been listed before 2006. The study adopted a panel approach with data having both cross-sectional and time dimensions. The study collected data from the year 2008 to 2014 from the 37 firms. During data collection, the study focused on the characteristics of the chief executive officer because the study variables sought to determine how these CEO characteristics can influence the firm's capital structure

The paper is organized as follows: In Section 2, we discuss related theories and formulate our hypotheses. Section 3 describes the way in which we constructed the sample and the specification of the model. Section 4 presents the results of our descriptive and multivariate analysis of the relationship between CEO characteristics and capital structure. Finally, Section 5 provides discussion and concluding remarks.

\subsection{Theory and hypotheses development}

The upper echelons theory is based on behavioral decision making and bounded rationality. The theory, developed by Hambrick and Mason (1984), hypothesizes that the demographic characteristics of decision makers have 
implications for firm outcomes. It proposes that organizational outcomes are related to the particular demographic characteristics of top level decision-makers. The core assumption underlying Hambrick and Mason's (1984) theory is the belief that demographic characteristics serve as surrogates for cognitive orientations, beliefs, values, perceptions and knowledge.

According to Hambrick (2007), CEOs act on the basis of their personal interpretations of given situations, and these interpretation are a function of their experience. Studies grounded in upper echelons theory contend that demographic characteristics such as age (Wiersema \& Bantel, 1992; Díaz-Fernández et al., 2019; Richardet et al., 2019), tenure (Chen et al.,2019), experience Zhang, 2019), educational level (Shahab et al., 2020), functional background (Chen et al., 2019), gender (Farrell \& Hersch, 2005).) and ethnicity (Carter et al., 2010) are important proxies for cognitive bias, and that these characteristics have an impact upon the ability to make decisions that enhance firm performance.

Although upper echelons theory is based on top management Hiebl (2014), it is important to note that boards of directors are involved in making decisions which have an effect upon firm performance Naciti (2019). Research indicates that the role of the board includes advising and monitoring, hiring and firing management and reviewing, approving, and facilitating strategic decisions (Jensen and Zajac, 2004; Tarus \& Aime, 2014; Johnson, et al., 2013). In the light of the theory it can be argued that to remain relevant in an increasingly competitive world, having the optimal mix of skills, expertise and experience is paramount to ensure that the board as a collective is equipped to guide the business and strategy any firm. Companies that fail to dip into the ever-deepening talent pool of diverse, well-educated and ambitious individuals run the risk of limiting value creation, compromising sustainability and undermining their long-term competitiveness (Squires, \& Elnahla, 2020). Thus, on the basis of these arguments, we examined optimal mix of skills which include CEO tenure, CEO gender, CEO age and CEO education in relation to capital structure

\subsection{CEO tenure}

Tenure of the board of directors means the average period the board members have been in their board positions ( Tejerina-Gaite, \& Fernández-Temprano, 2020). Board tenure reflects the likelihood that board members' control over the monitoring of executives will increase as the average tenure period increases (Graham, 2020). Most of the existing research has argued that lengthy CEO tenure is negatively related to leverage (Walters et al., 2007; Kaur \& Singh, 2019).). further it is that argued that longer tenure exacerbates entrenchment, which is an important aspect in decision-making (Zwiebel,1996). For example, Berger et al., (1997) argue that entrenched managers are likely to pursue lower leverage in the capital structure to avoid monitoring pressures relating to high levels of debt. Vafeas (2003) developed an expertise hypothesis suggesting that longer tenure leads to greater firm and industry knowledge, thereby improving the monitoring ability of the board members. The expertise hypothesis is used to argue that longer tenure is associated with improved director performance, because directors develop more expertise over time and become more willing to criticize the management (Bebchuk et al., 2002). Thus, longtenure boards are expected to have more information and experience at their disposal and, thus, to be able to provide more active monitoring and advice to management.

In general, upper echelons theory studies suggest longer-tenured CEOs initiate fewer strategic actions. In fact, some upper echelons theory scholars use CEO tenure to proxy constructs like persistence, commitment to the status quo, and rigidity (Finkelstein \& Hambrick, 1990; Graf-Vlachyet al., 2020). According to Matta \& Beamish, (2008) CEOs are more concerned about their legacies and are less willing to pursue new initiatives and launch risky investments that threaten those legacies and during their tenure, CEOs accumulate power, knowledge, and skills to resist pressure from other stakeholders (Meyer, 1975 and Boyer, 2005).). Longer-tenured CEOs, for example, have had more opportunities to handpick subordinates (Miller, 1991; Hambrick \& Fukutomi, 1991).) and nominate board members (Westphal, 1999 and Fan et al., 2019). Through these selections, CEOs can minimize dissent and surround themselves with people who have worldviews similar to their own (Acharya \& Pollock, 2013; Zajac \& Westphal, 1996a). Thus, as tenure increases, CEO autonomy may increase, and the pressure CEOs receive from other constituencies may decrease and willingness to initiate or fund new strategic actions declines as their tenure as CEO increases (Miller, 1991).

Conversely, CEOs tend to confront power struggles early in their tenure. During this time, for example, they are at higher risk of dismissal (Shen \& Cannella, 2002). Thus, CEOs are motivated to prove their competence and demonstrate their power, often by investing in major strategic actions, early in their tenure (Zona 2016). For example, strategic actions to change the firm's scope or strategy are a way for CEOs to exert their authority and begin to implement their visions for the firm. In addition, new CEOs may seek to co-opt or appease knowledgeable top management team or board members who provide mentoring and support early in their tenure (Shen, 2003). In turn, they may authorize strategic actions that are favored by these powerful individuals. Last, because shorttenured CEOs have less experience in the CEO position, it might be necessary for them to experiment with the different strategic actions available (Hambrick \& Fukutomi, 1991; Ferreira, et al., 2016). Thus, we posit that:

H1: CEO tenure is positively related to capital structure of listed firms in Kenya. 


\subsection{CEO Gender}

A considerable body of work has been conducted on the effects of director gender, much of which takes the stance that gender diversity affects board cognition, dynamics, and decision making and in turn, firm-level outcomes (Torchia, 2016). It's argued that gender diversity affects board dynamics but not the firm's bottom line (Terjesen, et al., (2009). Adams \& Ferreira (2009) reported that gender diverse boards are better in monitoring executive directors and show that women have a better attendance rate in board meetings than men. According to Alves et al., (2015) increased presence of female directors in the board could improve the effectiveness of the board, reduce information asymmetry between the management and outside investors, and consequently lead firms to have better access to external capital.

The claim that gender diversity has a positive role in firm performance may be supported from different theoretical perspectives. The first of these is agency theory, which is concerned with the independence of directors and the ability to monitor management (Bathala \& Rao, 1995). Research shows that gender diversity provides a board with the wherewithal to monitor management (Carter et al., 2003; Konrad et al., 2010; Terjesen et al., 2009). Studies suggest that having more women directors is an effective way of executing monitoring functions (Hillman et al., 2002; Carter et al., 2003). Women are likely to possess managerial skills such as legal, human resources, communication and public relations skills, as compared with men, who are more likely to possess the line functions of marketing and operations (Zelechowski and Bilimoria, 2004). It is argued that if women directors are known to be effective monitors, then investors will place higher valuation premiums on those firms with greater gender diversity in the boardroom Campbell et al., (2008).

Arfken et al., (2008), Nielsen \& Huse (2010) and Burgess \& Tharenou (2002) all explain the competitive benefits that can be enjoyed by firms employing women on boards of directors. They point to women having an intimate knowledge of consumer markets and customers and to women being innovative but also socially and community minded. A combination of changing social attitudes and stronger equality legislation appears to have had some effect in improving the participation of women on company boards as reported in US-based studies (Kang et al. 2007; Lückerath-Rovers 2013; Adams and Ferreira 2008). However, evidence from other developed countries is less encouraging. In the case of Australia, Kang et al. (2007) report that 33\% of companies have no female directors and $51 \%$ only have one woman on the board. In 2002, only $37 \%$ of companies in Tennessee had at least one female director on the board (Arfken et al., 2004).

There is a strong evidence to suggest that women participation is purely seen as a legitimating device in regard to internal and external stakeholders (Mahadeo, 2012; Adams and Ferreira 2008). As a result, the positive features of women participation in boards do not consistently emerge from empirical studies - at least not in a statistically significant way and in relation to financial outcomes. Nonetheless, Catalyst (2004) reports on 353 Fortune 500 companies in the United States over the period of 1996-2000. They found that companies with the highest representation of women on their top management teams had a 35\% better return on equity and 34\% better total return to shareholders than those companies with the lowest female representation. Farrell and Hersch (2005) also find that women tend to serve on better performing boards but overall there is little systematic evidence of direct links between gender diversity and performance. Alternatively, Adams and Ferreira's (2008) study uncovers both indirect and direct links and finds a positive link between gender and governance but also a positive relationship between return on assets and gender. Thus, we posit that:

H2: CEO Gender is positively related to capital structure of listed firms in Kenya.

\subsection{CEO Age}

In a research review, Hambrick and Mason (1984) hypothesized that age affects behavior relating to risk-seeking, novelty and information-seeking. Other empirical studies have showed that age is an important variable which influences behavior, beliefs, values and attitudes, as well as strategic orientation (Yang \& Wang, 2014; Herrmann and Datta, 2005). Kang et al., (2007) argued that there is inherent nature of company management and career progression does play a significant role in having a board which mainly consists of mature, experienced and by default older directors. Retired executives are generally seen as ideal non-executive board members (Krames, 2003) and appear more likely to be invited to sit on boards relative to other less experienced and younger age groups. According to Chen (2014), there is a significant relationship between capital structure and age plus experience of top employees. Firms with older and qualified board membership have low leverage or debt ratio. According to Yasser et al., (2015), there is a significant relationship between capital structure and CEO age. The finding concurs with Khurana (2004) that firms with older CEOs generally have low gearing levels. He argued that older CEOs exert pressure on managers to follow lower gearing levels and enhance firm performance. It is argued that age difference affects the capital structure decisions of managers and younger managers, more frequently select to operate in a more competitive environment than older do (Shan et al., 2020). However, the difference still exists not due to different risk aversion, but because young managers are more overconfident and there are age differences in preferences for performance in a competitive environment (Choi, 2018)

The arguments for promoting age homogeneity or heterogeneity at board level remain unconvincing from a 
functional perspective. Whilst an age-diverse board may enable some division of labour and encourage board development and learning, it relies on the assumption that directors will play their selected roles and does not address the likely short-term issues of communication and trust arising from generational gaps (Finkelstein \& Hambrick, 1996). On the other hand, a homogeneous board is likely to avoid these latter issues but composition may encourage complacency, cronyism, lack of interest in new ideas/strategies and decisions based on compromises. Thus, we posit that:

H3: CEO Age is positively related to capital structure of listed firms in Kenya.

\subsection{CEO Education}

Drawing upon upper echelons theory, Hambrick and Mason (1984) postulated that educational level is a measure of an individual's knowledge, skill base and cognitive skills. Similarly, social scientists have suggested that different educational levels are associated with varied social status, networking and professional development paths (Mirowsky \& Ross, 2003). Evidence from earlier studies interrogating the role of education has established a link between education and innovation levels (Wang \& Yin, 2018)

The educational background of the CEOs is believed to be positively related to debt, implying that bettereducated owners do have greater possibilities of borrowing (Abor, 2008). The studies on the effect of the education levels have focused mainly on the graduate level of education or MBA degrees. For instance, Kaplan et al., (2012) noted that education levels are considered as key determinants of corporate decisions. This would be particularly important if the owner had no book-keeping knowledge. According to Green et al., (2007) the level of education appears to have an important positive impact on micro and small enterprises' debt-raising capacities. There is no consistent, long-term relationship between CEO education and capital structure decision. Furthermore, there is no strong evidence of a relationship between CEO education and capital structure decision, while it is weak-and, perhaps, statistically insignificant.

Ting et al., (2015) who studied Malaysian firms and found that CEO education level positively correlated with leverage. Cronqvist, et al., (2012) observed that CEOs with MBAs are more comfortable with debt and thus they aggressively use more debt. Within Eastern Europe, Rakhmayil and Yuce (2009) observed firms ran by CEOs with MBA degrees, graduates from highly reputable business schools and with have professional certification tend to use higher leverage when compared to their counterparts.

Regarding the educational levels of the CEOs, Cronqvist, et al., (2012) indicated that CEOs with MBAs are more comfortable with debt, while CEOs from older age cohorts are not. In another study, Custódio and Metzger (2014) observed that educational levels have a significant role in the use of debt in corporate financing. The study indicated that CEOs with financial management backgrounds tend to use more debt notwithstanding the credit conditions.

The empirical studies on the education level of the CEO have shown a significant positive association with the corporate leverage decision such that executives with MBAs or graduate - level are more likely to issue debt instruments (Custódio \& Metzger, 2014). The empirical studies have been done on developed capital markets where the capital markets are vibrant as opposed to the country which has bank-based systems. These studies have elaborately considered developed with more emphasis on the developed capital markets. The differences in the context confer other researchers with an opportunity for studies in the burgeoning capital market in Sub - Saharan Africa. Indeed, many directors engage in occupations and activities that have little in common with their original professional or academic studies or they may have studied different subject areas (Chao et al., 2017). However, Boards with diverse educational levels are better equipped to enhance the quality of decision making by bringing in different perspectives. Thus, we posit that:

H4: CEO education is positively related to capital structure of listed firms in Kenya.

\subsection{Methods and data}

The data used in this study were derived from publicly listed firms in Kenya during the period 2008-2014. The total number of firms listed on the NSE, as at the end of 2014, was 64: these firms fall under different sectors of the economy, such as agricultural, commercial and services industry, telecommunications and technology, automobile and accessories, investment, manufacturing and allied and construction. Firms which issued initial public offers (IPOs) after 2008 and those that were delisted or suspended between 2008 and 2014 were excluded to offer consistency, precision, completeness and robustness of the result. Therefore, the the total number of firms used in the study was 37 , yielding a total of 264 firm year observations.

The study was conducted using secondary sources which were achieved by analyzing the content of financial reports of 37 companies quoted in NSE Kenya. This was suitable for this study because all the audited information about the NSE firms was readily available for the public as required by the company law of Kenya.

\subsection{Measurement of Variables}

Capital structure was measured as ratio of debt to equity (Titman \& Wessels, 1988).) While CEO tenure was 
measured by counting the years that a chief executive has been in office (Ali \& Zhang, 2015). CEO age was measured using a number of years ages (Dagsson, 2011). CEO education was measured by the level of education (King et al., 2016) and finally gender was measured using a dummy variable, where male were coded as 1 and female 0 (King et al., 2016).

The study incorporated control variables into the analysis, firm size and firm performance is known to affect capital structure. Firm size was measured as a natural log of total assets (Titman \& Wessels, 1988). This was controlled because previous studies have found firm size to be positively related to leverage (Friend and Lang, 1988; Nwachukwu and Mohammed, 2012), whereas others have found it to be negatively related (Rajan and Zingales, 1995). Large firms may use more leverage in their capital structure because of the availability of tangible assets to secure debts (Nicodano \& Regis, 2019)

The study also controlled for firm performance, because of strong indications of its effect on capital structure (Le and Phan, 2017). For example, pecking order theory postulates that firms generating profits finance their assets from retained profits first before resorting to debts. Thus, a negative relationship was found between profitability and leverage (Myers and Majluf, 1984). Consistent with previous studies, we calculated firm performance as earnings before depreciation, interest and tax divided by total assets (Nwachukwu and Mohammed, 2012).

\subsection{Model specification}

The regression model which assumes linearity, normality, constant and independence is as follow

\subsection{Model specification}

The panel regression model takes the following format

$\mathbf{Y}=\boldsymbol{\beta}_{0}+\boldsymbol{\beta}_{1 \mathrm{it}} \mathbf{X}_{1 \mathrm{it}}+\boldsymbol{\beta}_{2 \mathrm{it}} \mathbf{X}_{2 \mathrm{it}}+\boldsymbol{\beta}_{3 \mathrm{it}} \mathbf{X}_{3 \mathrm{it}}+\boldsymbol{\beta}_{4 \mathrm{it}} \mathbf{X}_{4 \mathrm{it}}+\boldsymbol{\mu}_{\mathrm{it}}$

Where;

$\mathbf{Y}=$ Capital Structure (Dependent variable)

$\mathbf{X}_{1 \text { it }}=$ CEO tenure $\quad($ Independent variable 1$)$

$\mathbf{X}_{\mathbf{2 i t}}=$ CEO gender $\quad$ (Independent variable 2)

$\mathbf{X}_{3 \mathbf{i t}}=$ CEO Age (Independent variable 3)

$\mathbf{X}_{4 i t}=$ CEO education (Independent variable 4)

$\boldsymbol{\varepsilon}=$ the error term

$\boldsymbol{\beta}_{0}=$ Constant

$\boldsymbol{\beta}_{1 \ldots} \boldsymbol{\beta}_{4},=$ Coefficients of the X (independent) variables.

$x_{i t} \ldots$ is a $1 \times k$ vector of observations on the explanatory variables, $t=1, \ldots, T ; i=1, \ldots, N$.

\section{Results}

\subsection{Descriptive results}

Table 4.1 presents a summary of descriptive statistics of the dependent and independent variables used in the study. The statistics of capital structure of the firms had a mean of 8.79 with the standard deviations of 16.96. CEO tenure showed a mean of 6.76 and standard deviations of 3.27 suggesting that majority CEOs in NSE firms hold an average of 5 years or most contracts of employment ends at the fifty year. The longest CEO tenure in NSE is indicated to be 14 year. Result further indicates that the average age for the CEOs for publicly listed firms in Kenya is 48 years and it is dominated by males. The study found that majority of CEOs in NSE holds Master's degree suggesting that for one to be a CEO, it requires high academic achievements.

Table 4.1 Descriptive Statistics for Capital structure, CEO tenure, CEO age, CEO gender and education

\begin{tabular}{lllll}
\hline Variable & Mean & Std. Dev. & Min & Max \\
\hline Capital Structure & 8.79 & 16.96 & 0 & 129.29 \\
CEO Tenure & 6.76 & 3.27 & 1 & 14 \\
CEO Gender & 1.06 & .231 & 1 & 2 \\
CEO Age & 48.32 & 6.58 & 32 & 64 \\
CEO Education & 1.55 & .548 & 1 & 3 \\
\hline
\end{tabular}

\subsection{Correlation results}

Table 4.2 presents Pearson correlation results for the variables used to assess its association. The findings shows that CEO tenure was negatively and significantly correlated to capital structure $(r=-0.29, \rho<0.01)$ suggesting that as the tenure of the CEO increases it reduces capital structure of a firm. Additionally, CEO age was indicated to be positively related with capital structure $(r=0.192, \rho<0.01)$ suggesting that CEOs' age at an average of 48 year is likely to initiates changes to capital structure in a positive away. CEO education is negatively and significantly correlated to capital structure $(r=-0.177, \rho<0.01)$ suggesting advanced education of a doctoral-level degree in business, engineering, science, and other fields) is likely to equip directors with skills in research that facilitate assessment of research projects in the local firm. It may provide them with knowledge related to innovation 
management. However, boards can be configured to improve efficiencies, thereby reducing R\&D spending. CEO gender is negatively and significantly correlated to capital structure $(r=-0.08, \rho<0.01)$ however this relationship is very negligible suggesting that CEOs gender have lower leverage. The association of the control variables showed that, firm performance, board size and firm size has negligible association with capital structure.

Table 4.2 Correlation results

\begin{tabular}{|c|c|c|c|c|c|c|c|}
\hline & $\begin{array}{l}\text { Capital } \\
\text { structure }\end{array}$ & $\begin{array}{l}\text { CEO } \\
\text { tenure }\end{array}$ & $\begin{array}{l}\text { CEO } \\
\text { gender }\end{array}$ & $\begin{array}{l}\text { CEO } \\
\text { age }\end{array}$ & $\begin{array}{l}\text { CEO } \\
\text { education }\end{array}$ & $\begin{array}{l}\text { Firm } \\
\text { performanc } \\
\text { e }\end{array}$ & $\begin{array}{l}\text { Firm } \\
\text { size }\end{array}$ \\
\hline Capital structure & 1 & & & & & & \\
\hline CEO tenure & $-.29 * *$ & 1 & & & & & \\
\hline CEO gender & -.08 & -.03 & 1 & & & & \\
\hline CEO age & $.19 * *$ & -.02 & .01 & 1 & & & \\
\hline CEO education & $-.18 * *$ & $.12 *$ & $-.13 *$ & $.24 * *$ & 1 & & \\
\hline $\begin{array}{l}\text { Firm } \\
\text { performance }\end{array}$ & -0.02 & 0.03 & 0.03 & 0.08 & -0.02 & 1 & \\
\hline Firm size & -0.03 & 0.00 & 0.00 & -0.01 & -0.08 & -0.03 & 1 \\
\hline
\end{tabular}

\subsection{Diagnostics Statistics}

\subsubsection{Heteroskedasticity}

Heteroskedasticity was tested using the Breusch-Pagan test; (Breusch and Pagan 1979) the test is used to test for heteroskedasticity in a linear regression model. It tests whether the variance of the errors from a regression is dependent on the values of the independent variables. The statistic test of heteroskedasticity of this study indicated a chi2 $(5)=94.78$ and Prob $>$ chi $2=0.0000$. According to Breusch and Pagan, (1979) if the test statistic has a pvalue below an appropriate threshold $(p<0.05)$ then the null hypothesis of homoskedasticity is rejected and heteroskedasticity assumed.

\subsection{Model Selection- The Hausman test}

According to Baltagi, (2008) there are a variety options to estimates a panel data regression model. These approaches are ordinary least squares (OLS), fixed effects, and random effects. Each estimator has some specific assumptions of the error term. While OLS does not take into account firm individual effects and period specific effects, fixed effects and random effects control for these elements.

The study used The Hausman test for the random effects versus the fixed effect model in order to determine the proper model. According to Clark and Linzer, (2015) fixed effects and random effects are two options that are widely used in panel data regression analysis. However, which one should be applied depends on the standard Hausman test (Baltagi, 2008).

According to Greene (2003) the Hausman test is a useful device for determining the preferred specification of the common effects model. Random effects and fixed effects estimations are based on different assumptions that whether the unobserved factors are correlated with independent variables in the model. While the fixed effects estimator allows the unobserved effects to be arbitrarily correlated with the included explanatory variables, the random effects approach assumes the unobserved individual effects are uncorrelated with the observed explanatory variables (Hsiao, 2014).

In this case, fixed effects model is appropriate. Shown in table 4.4 the Hausman test calculates the value of $\mathrm{P}=0.2398$ hence, fixed effect estimate is proper for data analysis. Furthermore, Hausman test compares an estimator (b) that is known to be consistent with an estimator (B) that is efficient under the assumption being tested. The null hypothesis is that the estimator (b) is indeed an efficient (and consistent) estimator of the true parameters. If this is the case, there should be no systematic difference between the two estimators. If there an exists a systematic difference in the estimates, you have reason to doubt the assumptions on which the efficient estimator is based (Hausman, 1978). 
Table 4.4 Housman random fixed

\begin{tabular}{lccc}
\multicolumn{4}{c}{---- Coefficients ---- } \\
\hline & (b) fe & (B)re & Difference (b-B) \\
\hline CEO tenure & -1.364 & -1.192 & -.172 \\
CEO gender & -7.205 & -7.152 & -.053 \\
CEO age & .5337 & .5547 & -.021 \\
CEO education & -5.630 & -5.273 & -.357 \\
\hline
\end{tabular}

$\mathrm{b}=$ consistent under Ho and Ha; obtained from xtreg

$\mathrm{B}=$ inconsistent under Ha, efficient under Ho; obtained from xtreg

Test: Ho: difference in coefficients not systematic

$\operatorname{chi} 2(5)=(\mathrm{b}-\mathrm{B})^{\prime}\left[(\mathrm{V} \text { b-V B })^{\wedge}(-1)\right](\mathrm{b}-\mathrm{B})=6.75$

Prob $>$ chi $2=0.2398$

\subsection{Empirical results}

Table 4.6 illustrates the coefficient estimates of CEO tenure to be significant at $(\beta=-1.36, \rho<0.05)$, hence we concluded that CEO tenure has a negative and significant effect on capital structure, this suggest that entrenched CEOs employ lower debt in order to reduce the performance pressures associated with high debt capital. CEO gender had negative and insignificant effect on capital structure $(\beta=-7.20, \rho>0.05)$. This suggests that the presence of gender diversity does not offer better insight on the adjustment process toward the target debt-to-equity ratio. Table 4.6 further illustrated the coefficient estimates of CEO age to be significant at $(\beta=.533, \rho<0.05)$ this suggest that older executives are more likely to initiate changes positively. For example old executives is deemed to have a diverse experience and well conversant with the industry-level determinants of financial leverage of the company than young executives therefore prompting better leverage. Finally table 4.6 indicated that CEO education had negative effect and it's significant on capital structure $(\beta=5.55, \rho=<0.05)$, this suggests that boards can be configured to improve efficiencies, thereby reducing R\&D spending. Further since most CEOs of listed firms in Kenya possess advanced degrees there is likelihood that these firms engage large research and development (R\&D). If a large $R \& D$ intensity relative to one's industry peers indicates that the firm is trying to be an innovator, then there is good reason to predict that it will also want to maintain low leverage

The empirical analysis of the study as indicated in table 4.5 shows that the control variables of the study that is firm performance and firm size had no influence on the effect of CEO's characteristics and capital structure

Table 4.5 illustrates the coefficient estimates of CEO characteristics and capital structure before the controlled variables in publicly listed firms in Kenya

\begin{tabular}{|c|c|c|c|c|c|c|}
\hline \multicolumn{7}{|c|}{ Fixed-effects (within) regression with the Number of obs $=264$} \\
\hline Capital structure & Coefficient & Std. Err & $\mathrm{t}$ & $\mathrm{P}>|\mathrm{t}|$ & & \\
\hline CEO tenure & -1.364 & .289 & -4.72 & 0.000 & & \\
\hline CEO gender & -7.205 & 3.925 & -1.84 & 0.084 & & \\
\hline CEO age & .533 & .141 & 3.76 & 0.000 & & \\
\hline CEO education & 5.550 & 1.737 & -3.24 & 0.001 & & \\
\hline Firm performance & -.071 & .284 & -0.25 & 0.802 & & \\
\hline firm size & -.079 & .0622 & -1.29 & 0.200 & & \\
\hline & & & & Prob $>F$ & $=$ & 0.0954 \\
\hline & & & & $\mathrm{R}$ sqr & & 0.2692 \\
\hline
\end{tabular}

Table 4.6 illustrates the coefficient estimates of CEO characteristics and capital structure after the controlled variables in publicly listed firms in Kenya

\begin{tabular}{|c|c|c|c|c|c|c|}
\hline \multicolumn{7}{|c|}{ Fixed-effects (within) regression with the Number of obs $=264$} \\
\hline Capital structure & Coefficient & Std. Err. & $\mathrm{t}$ & $\mathrm{P}>|\mathrm{t}|$ & & \\
\hline CEO tenure & -1.364 & .289 & -4.72 & 0.000 & & \\
\hline CEO gender & -7.205 & 3.925 & -1.84 & 0.068 & & \\
\hline CEO age & .533 & .141 & 3.76 & 0.000 & & \\
\hline \multirow[t]{4}{*}{ CEO education } & 5.550 & 1.737 & -3.24 & 0.001 & & \\
\hline & & & & $\mathrm{F}$ & & 6,252 \\
\hline & & & & Prob $>$ F & $=$ & 0.0000 \\
\hline & & & & $\mathrm{R}$ sqr & & .287 \\
\hline
\end{tabular}

\section{Discussion and conclusions}

The study established that CEO tenure has a negative and significant effect on the capital structure. According to Walters et al., (2007) long tenure of CEOs increases their credibility and independence, making them 
overconfident hence complacent subordinates becomes reluctant to challenge anything which could influence their capital structure decision making skills. In a similar nature, long tenure magnifies a CEOs ego to the extent that/he may think that he can do no wrong, even if her/his action could jeopardize debt equity. This negatively impact on firms' capital structure. Myers, (2001) showed a negative relationship between executive firm tenure and capital structure. However, prior authors (Frank \& Goyal, 2008; Graham, \& Leary (2011) propose a positive relationship between tenure and capital structure on the basis that tenure improves the experience of the CEO, which consequently decreases his reliance on subordinates and so makes delegation of decisions including leverage less frequent. Nonetheless, in terms of board tenure, a board with a long tenure tends to run a good supervision in order to achieve the company's goals (Farag \& Mallin, 2019). Simply because the longer the tenure of directors on the board, the better knowledge of company and their executives they will get. The study findings are in line with the prior literature with regard to the negative influence of CEO tenure on capital structure.

With respect to CEO gender, the finding of the study showed that CEO gender had negative and insignificant effect on capital structure. The findings concur with Jianakoplos and Bernasek (1998) and (Ali, et al., 2011) who found that single women are more risk-averse than single men in capital structure decisions. Additionally, Niessen and Ruenzi (2007) are of the opinion that female fund managers are more risk-averse than male fund managers in their investment decisions which could influence the liquidity and debt equity ratio of a company. Furthermore, Bennedsen et al., (2006) argued that the control of female CEOs grow slower than firms under the control of male CEOs. Besides, Zeng \& Wang (2015) argued that gender, affects investment-cash flow sensitivity and corporate investments made by male CEOs are more sensitive to cash flow, particularly in the equity dependent companies, compared to investments made by female CEOs.

Concerning the CEO age, the finding of the study showed that that CEO age has a positive and significant effect on capital structure. This implies that the CEOs ability to bear risk could be shaped by his or her age thus influencing his capital structure decision making skills. Consistently, prior literature indicates that the structure of responsibility and power of decision making in publicly traded companies is hierarchical according to the age of top executives. As such, the CEO who is an older person is at the top and is influential in capital structure decision making Graham, et al., (2010) According to Niederle and Vesterlund (2007) age difference affects the capital structure decisions of managers. Similarly, to Graham, et al., (2010) there is a significant relationship between capital structure and age plus experience of top employees. Consistently, Abor (2007) also show a positive relationship between age of the qualified board and financial leverage (capital structure). In addition, Naseem, (2019) showed that there is a significant relationship between capital structure and CEO age.

Finally the study found that CEO education has a positive and significant effect on capital structure. The results is Contrary that of Naseem, (2019) who noted that the educational background of the CEOs is believed to be positively related to debt, implying that better educated owners do have greater possibilities of borrowing. As well, the level of education appears to have an important positive impact on micro and small enterprises' debtraising capacities (Green et al., 2007).

\subsection{Conclusion}

This study examined the effect of CEOs characteristics on capital structure of publicly listed firms in Kenya. On CEO tenure, the study has established that CEO tenure has a negative effect on the capital structure. As CEOs acquire firm specific knowledge early in their tenure, the result is better firm performance. Eventually as tenure continues to advance, boards lose their oversight and firms engage in more value-destroying activity. The study furthermore concludes that, majority of the CEOs are male. The CEO position for the firms listed in NSE is therefore male dominated. Gender diversity is likely to bring on board a wide array of individuals that are knowledgeable and conversant with the management of the firms. However, the study has indicated that CEO gender has no significant effect on the capital structure. There is thus need for further studies on the same so as to validate this concept. We further found that CEO age has a positive and significant effect on the capital structure. The average age for the CEOs is 48 years. This is an indication that the CEOs are older individuals. The CEOs are therefore more likely to pursue lower leverage or debt ratio so as to enhance the firm performance. Finally the existence of educated CEOs could lead to better management decisions and help firms in attracting better resources, the study has indicated that CEO education has a negative effect on the capital structure. It can therefore be inferred that the more educated the CEO gets, the more cautious he/she becomes of the risk of bankruptcy lied in debt. As a result, firms will have less capacity to borrow in times where financing is necessary.

\subsection{Further Research Recommendations}

The study focused on the effect of CEO characteristics on capital structure of publicly listed firms in Kenya. The results are confirmable to the literature in international setting. However, further insight into the idea is needed to support the findings. This study therefore recommends that another study be done to augment finding in this study; it therefore recommends a study be done on more number of firms rather than including only firms in the NSE for the sake of generalizing the results of the study. Moreover, including moderator factors can also be made in the 
research models of the new research by other scholars in future.

\section{Reference}

Abor, J. (2008). Agency theoretic determinants of debt levels: evidence from Ghana. Review of Accounting and finance.

Acharya, A. G., \& Pollock, T. G. (2013). Shoot for the stars? Predicting the recruitment of prestigious directors at newly public firms. Academy of Management Journal, 56(5), 1396-1419.

Ali, A., \& Zhang, W. (2015). CEO tenure and earnings management. Journal of Accounting and Economics, 59(1), 60-79.

Ali, M., Kulik, C. T., \& Metz, I. (2011). The gender diversity-performance relationship in services and manufacturing organizations. The International Journal of Human Resource Management, 22(07), 14641485.

Alves, P., Couto, E. B., \& Francisco, P. M. (2015). Board of directors' composition and capital structure. Research in International Business and Finance, 35, 1-32.

Arfken, D. E., Bellar, S. L., \& Helms, M. M. (2004). The ultimate glass ceiling revisited: The presence of women on corporate boards. Journal of Business ethics, 50(2), 177-186.

Arfken, D. E., Bellar, S. L., \& Helms, M. M. (2004). The ultimate glass ceiling revisited: The presence of women on corporate boards. Journal of Business ethics, 50(2), 177-186.

Artikis, G. P., Eriotis, N., Vasiliou, D., \& Ventoura-Neokosmidi, Z. (2007). How firm characteristics affect capital structure: an empirical study. Managerial Finance.

Bae, K. H., Kang, J. K., \& Wang, J. (2011). Employee treatment and firm leverage: A test of the stakeholder theory of capital structure. Journal of financial economics, 100(1), 130-153.

Baltagi, B. H. (2008). Forecasting with panel data. Journal of forecasting, 27(2), 153-173.

Bancel, F., \& Mittoo, U. R. (2004). Cross-country determinants of capital structure choice: a survey of European firms. Financial management, 103-132.

Barton, S. L., \& Gordon, P. J. (1988). Corporate strategy and capital structure. Strategic management journal, 9(6), 623-632.

Bathala, C. T., \& Rao, R. P. (1995). The determinants of board composition: An agency theory perspective. Managerial and decision economics, 16(1), 59-69.

Bebchuk, L. A., Fried, J. M., \& Walker, D. I. (2002). Managerial power and rent extraction in the design of executive compensation (No. w9068). National bureau of economic research.

Bennedsen, M., Perez-Gonzalez, F., \& Wolfenzon, D. (2006). Do CEOs Matter?.

Berger, P. G., Ofek, E., \& Yermack, D. L. (1997). Managerial entrenchment and capital structure decisions. The journal of finance, 52(4), 1411-1438.

Blake, A. (2016). Dynamic directors: Aligning board structure for business success. Springer.

Boyer, R. (2005). From shareholder value to CEO power: The paradox of the 1990s. Competition \& Change, 9(1), 7-47.

Breusch, T. S., \& Pagan, A. R. (1979). A simple test for heteroscedasticity and random coefficient variation. Econometrica: Journal of the Econometric Society, 1287-1294.

Burgess, Z., \& Tharenou, P. (2002). Women board directors: Characteristics of the few. Journal of business ethics, 37(1), 39-49.

Campbell, K., \& Mínguez-Vera, A. (2008). Gender diversity in the boardroom and firm financial performance. Journal of business ethics, 83(3), 435-451.

Carter, D. A., D'Souza, F., Simkins, B. J., \& Simpson, W. G. (2010). The gender and ethnic diversity of US boards and board committees and firm financial performance. Corporate Governance: An International Review, 18(5), 396-414.

Catalyst. (2004). The bottom line: Connecting corporate performance and gender diversity. Catalyst.

Chao, C. C., Hu, M., Munir, Q., \& Li, T. (2017). The impact of CEO power on corporate capital structure: New evidence from dynamic panel threshold analysis. International Review of Economics \& Finance, 51, 107-120.

Chen, W. H., Kang, M. P., \& Butler, B. (2019). How does top management team composition matter for continual growth? Reinvestigating Penrose's growth theory through the lens of upper echelons theory. Management Decision.

Chen, W. H., Kang, M. P., \& Butler, B. (2019). How does top management team composition matter for continual growth? Reinvestigating Penrose's growth theory through the lens of upper echelons theory. Management Decision.

Choi, P. M. S., Chung, C. Y., \& Liu, C. (2018). Self-attribution of overconfident CEOs and asymmetric investment-cash flow sensitivity. The North American Journal of Economics and Finance, 46, 1-14.

Cronqvist, H., Makhija, A. K., \& Yonker, S. E. (2012). Behavioral consistency in corporate finance: CEO personal and corporate leverage. Journal of financial economics, 103(1), 20-40. 
Custódio, C., \& Metzger, D. (2014). Financial expert CEOs: CEO' s work experience and firm' s financial policies. Journal of Financial Economics, 114(1), 125-154.

Cytonn Annual Markets Review - 2016 - Cytonn Investments

Dagsson, S., \& Larsson, E. (2011). How age diversity on the Board of Directors affects Firm Performance.

Dallas, L. L. (2001). The new managerialism and diversity on corporate boards of directors. Tul. L. Rev., 76, 1363.

Datta, D. K., \& Rajagopalan, N. (1998). Industry structure and CEO characteristics: An empirical study of succession events. Strategic Management Journal, 19(9), 833-852.

Díaz-Fernández, M. C., González-Rodríguez, M. R., \& Simonetti, B. (2019). The moderating role of top management team diversity in strategic change in a multicultural context. European Management Review, 16(4), 957-973.

Downar, B., \& Keiling, M. (2019). Shareholder Rights and Capital Structure: Evidence from Derivative Lawsuits. Available at SSRN 3511349.

Fama, E. F. (1980). Agency problems and the theory of the firm. Journal of political economy, 88(2), 288-307.

Fan, Y., Boateng, A., King, T., \& MacRae, C. (2019). Board-CEO friendship ties and firm value: Evidence from US firms. International Review of Financial Analysis, 65, 101373.

Farag, H., \& Mallin, C. (2019). Monitoring corporate boards: evidence from China. The European Journal of Finance, 25(6), 524-549.

Farrell, K. A., \& Hersch, P. L. (2005). Additions to corporate boards: The effect of gender. Journal of Corporate finance, 11(1-2), 85-106.

Farrell, K. A., \& Hersch, P. L. (2005). Additions to corporate boards: The effect of gender. Journal of Corporate finance, 11(1-2), 85-106.

Ferreira, P., Klarner, P., \& Raisch, S. (2016). Staying agile in the saddle: CEO tenure, TMT characteristics, and organizational ambidexterity. In Academy of Management Proceedings (Vol. 2016, No. 1, p. 15877). Briarcliff Manor, NY 10510: Academy of Management.

Finkelstein, S., \& Hambrick, D. C. (1996). Strategic leadership: Top executives and their effects on organizations. Minneapolis, MN: West Publishing Company.

Frank, M. Z., \& Goyal, V. K. (2008). Trade-off and pecking order theories of debt. In Handbook of empirical corporate finance (pp. 135-202). Elsevier.

Frank, M. Z., \& Goyal, V. K. (2008). Trade-off and pecking order theories of debt. In Handbook of empirical corporate finance (pp. 135-202). Elsevier.

Friend, I., \& Lang, L. H. (1988). An empirical test of the impact of managerial self-interest on corporate capital structure. the Journal of Finance, 43(2), 271-281.

Gottardo, P., \& Moisello, A. M. (2014). The capital structure choices of family firms. Managerial Finance.

Graf-Vlachy, L., Bundy, J., \& Hambrick, D. C. (2020). Effects of an Advancing Tenure on CEO Cognitive Complexity. Organization Science.

Graham, J. R., \& Leary, M. T. (2011). A review of empirical capital structure research and directions for the future. Annu. Rev. Financ. Econ., 3(1), 309-345.

Graham, J. R., Kim, H., \& Leary, M. (2020). CEO-board dynamics. Journal of Financial Economics.

Green, C. J., Kimuyu, P., Manos, R., \& Murinde, V. (2007). How do small firms in developing countries raise capital? Evidence from a large-scale survey of Kenyan micro and small-scale enterprises. Advances in Financial Economics, 12, 379-404.

Green, C. J., Kimuyu, P., Manos, R., \& Murinde, V. (2007). How do small firms in developing countries raise capital? Evidence from a large-scale survey of Kenyan micro and small-scale enterprises. Advances in Financial Economics, 12, 379-404.

Greene, W. H. (2003). Econometric analysis. Pearson Education India.

Hambrick, D. C. (2007). Upper echelons theory: An update.

Hambrick, D. C., \& Fukutomi, G. D. (1991). The seasons of a CEO's tenure. Academy of management review, 16(4), 719-742.

Hambrick, D. C., \& Mason, P. A. (1984). Upper echelons: The organization as a reflection of its top managers. Academy of management review, 9(2), 193-206.

Harris, M., \& Raviv, A. (1991). The theory of capital structure. the Journal of Finance, 46(1), 297-355.

Hausman, J. A. (1978). Specification tests in econometrics. Econometrica: Journal of the econometric society, $1251-1271$.

Herrmann, P., \& Datta, D. K. (2005). Relationships between top management team characteristics and international diversification: An empirical investigation. British Journal of Management, 16(1), 69-78.

Hiebl, M. R. (2014). Upper echelons theory in management accounting and control research. Journal of Management Control, 24(3), 223-240.

Hillman, A. J., Cannella Jr, A. A., \& Harris, I. C. (2002). Women and racial minorities in the boardroom: How do directors differ?. Journal of management, 28(6), 747-763. 
Hsiao, C. (2014). Analysis of panel data (No. 54). Cambridge university press.

Ilona, D., Zaitul, Z., \& Ethika, E. (2019). Supervisory Board and Company Borrowing: The Case of Developing Economics. Journal of Reviews on Global Economics, 8, 730-738.

Jensen, M. C., \& Meckling, W. H. (1976). Theory of the firm: Managerial behavior, agency costs and ownership structure. Journal of financial economics, 3(4), 305-360.

Jensen, M., \& Zajac, E. J. (2004). Corporate elites and corporate strategy: How demographic preferences and structural position shape the scope of the firm. Strategic Management Journal, 25(6), 507-524.

Jensen, M., \& Zajac, E. J. (2004). Corporate elites and corporate strategy: How demographic preferences and structural position shape the scope of the firm. Strategic Management Journal, 25(6), 507-524.

Jianakoplos, N. A., \& Bernasek, A. (1998). Are women more risk averse?. Economic inquiry, 36(4), 620-630.

Johnson, S. G., Schnatterly, K., \& Hill, A. D. (2013). Board composition beyond independence: Social capital, human capital, and demographics. Journal of management, 39(1), 232-262.

Kang, H., Cheng, M., \& Gray, S. J. (2007). Corporate governance and board composition: Diversity and independence of Australian boards. Corporate Governance: An International Review, 15(2), 194-207.

Kaplan, S. N. (1994). Top executive rewards and firm performance: A comparison of Japan and the United States. Journal of political economy, 102(3), 510-546.

Kaplan, S. N., Klebanov, M. M., \& Sorensen, M. (2012). Which CEO characteristics and abilities matter?. The Journal of Finance, 67(3), 973-1007.

Katmon, N., Mohamad, Z. Z., Norwani, N. M., \& Al Farooque, O. (2019). Comprehensive board diversity and quality of corporate social responsibility disclosure: evidence from an emerging market. Journal of business ethics, 157(2), 447-481.

Kaur, R., \& Singh, B. (2019). Do CEO characteristics explain firm performance in India?. Journal of Strategy and Management.

Khurana, R. (2004). Searching for a corporate savior: The irrational quest for charismatic CEOs. Princeton University Press.

King, T., Srivastav, A., \& Williams, J. (2016). What's in an education? Implications of CEO education for bank performance. Journal of Corporate Finance, 37, 287-308.

Konrad, A. M., Cannings, K., \& Goldberg, C. B. (2010). Asymmetrical demography effects on psychological climate for gender diversity: Differential effects of leader gender and work unit gender composition among Swedish doctors. Human Relations, 63(11), 1661-1685.

Kroll, M., Walters, B. A., \& Wright, P. (2008). Board vigilance, director experience, and corporate outcomes. Strategic Management Journal, 29(4), 363-382.

Le, T. P. V., \& Phan, T. B. N. (2017). Capital structure and firm performance: Empirical evidence from a small transition country. Research in international business and finance, 42, 710-726.

Lööf, H. (2004). Dynamic optimal capital structure and technical change. Structural Change and Economic Dynamics, 15(4), 449-468.

Lückerath-Rovers, M. (2013). Women on boards and firm performance. Journal of Management \& Governance, 17(2), 491-509.

Mahadeo, J. D., Soobaroyen, T., \& Hanuman, V. O. (2012). Board composition and financial performance: Uncovering the effects of diversity in an emerging economy. Journal of business ethics, 105(3), 375-388.

Majumdar, S. K., \& Chhibber, P. (1999). Capital structure and performance: Evidence from a transition economy on an aspect of corporate governance. Public choice, 98(3-4), 287-305.

Malmendier, U. (2018). Behavioral corporate finance. In Handbook of Behavioral Economics: Applications and Foundations 1 (Vol. 1, pp. 277-379). North-Holland.

Matta, E., \& Beamish, P. W. (2008). The accentuated CEO career horizon problem: Evidence from international acquisitions. Strategic Management Journal, 29(7), 683-700.

Miller, D. (1991). Stale in the saddle: CEO tenure and the match between organization and environment. Management science, 37(1), 34-52.

Miller, M. H. (1977). Debt and taxes. the Journal of Finance, 32(2), 261-275.

Mirowsky, J., \& Ross, C. E. (2003). Education, social status, and health. Transaction Publishers.

Modigliani, F., \& Miller, M. H. (1958). The cost of capital, corporation finance and the theory of investment. The American economic review, 48(3), 261-297.

Modigliani, F., \& Miller, M. H. (1963). Corporate income taxes and the cost of capital: a correction. The American economic review, 53(3), 433-443.

Myers, S. C. (1977). Determinants of corporate borrowing. Journal of financial economics, 5(2), 147-175.

Myers, S. C. (1984). Capital structure puzzle (No. w1393). National Bureau of Economic Research.

Myers, S. C. (2001). Capital structure. Journal of Economic perspectives, 15(2), 81-102.

Myers, S. C., \& Majluf, N. S. (1984). Corporate financing and investment decisions when firms have informationthat investors do not have (No. w1396). National Bureau of Economic Research. 
Myers, S. C., \& Majluf, N. S. (1984). Corporate financing and investment decisions when firms have informationthat investors do not have (No. w1396). National Bureau of Economic Research.

Naciti, V. (2019). Corporate governance and board of directors: The effect of a board composition on firm sustainability performance. Journal of Cleaner Production, 237, 117727.

Naseem, M. A., Lin, J., ur Rehman, R., Ahmad, M. I., \& Ali, R. (2019). Does capital structure mediate the link between CEO characteristics and firm performance?. Management Decision.

Naseem, M. A., Lin, J., ur Rehman, R., Ahmad, M. I., \& Ali, R. (2019). Does capital structure mediate the link between CEO characteristics and firm performance?. Management Decision.

Nicodano, G., \& Regis, L. (2019). A trade-off theory of ownership and capital structure. Journal of Financial Economics, 131(3), 715-735.

Nielsen, S., \& Huse, M. (2010). Women directors' contribution to board decision-making and strategic involvement: The role of equality perception. European Management Review, 7(1), 16-29.

Niessen, A., \& Ruenzi, S. (2007). Sex matters: Gender differences in a professional setting (No. 06-01). CFR Working Paper.

Nwachukwu, J., \& Mohammed, D. (2012). Business risk, industry affiliation, and corporate capital structure: evidence from publicly listed Nigerian companies. Journal of African Business, 13(1), 5-15.

Nwachukwu, J., \& Mohammed, D. (2012). Business risk, industry affiliation, and corporate capital structure: evidence from publicly listed Nigerian companies. Journal of African Business, 13(1), 5-15.

Oduor, J., \& Kebba, J. (2019). Financial Sector Regulation and Governance in Africa. In Extending Financial Inclusion in Africa (pp. 137-163). Academic Press.

Rajan, R. G., \& Zingales, L. (1995). What do we know about capital structure? Some evidence from international data. The journal of Finance, 50(5), 1421-1460.

Rajan, R. G., \& Zingales, L. (1995). What do we know about capital structure? Some evidence from international data. The journal of Finance, 50(5), 1421-1460.

Rakhmayil, S., \& Yuce, A. (2009). Do CEO Qualifications Affect Capital Structure?. The Journal of Applied Business and Economics, 9(2), 76.

Richard, O. C., Wu, J., Markoczy, L. A., \& Chung, Y. (2019). Top management team demographic-faultline strength and strategic change: What role does environmental dynamism play?. Strategic Management Journal, 40(6), 987-1009.

Saona, P., San Martín, P., \& Jara, M. (2018). Group affiliation and ownership concentration as determinants of capital structure decisions: Contextualizing the facts for an emerging economy. Emerging Markets Finance and Trade, 54(14), 3312-3329.

Shahab, Y., Ntim, C. G., Chen, Y., Ullah, F., Li, H. X., \& Ye, Z. (2020). Chief executive officer attributes, sustainable performance, environmental performance, and environmental reporting: New insights from upper echelons perspective. Business Strategy and the Environment, 29(1), 1-16.

Shan, C. M., Ab Razak, N. H., Nassir, A. M., \& Yahya, M. H. (2020). CEO AGE AND THE DYNAMIC CAPITAL STRUCTURE EVIDENCE FROM MALAYSIA. Malaysian Journal of Business and Economics (MJBE).

Shen, W. (2003). The dynamics of the CEO-board relationship: An evolutionary perspective. Academy of Management Review, 28(3), 466-476.

Squires, B., \& Elnahla, N. (2020). The roles played by boards of directors: an integration of the agency and stakeholder theories. Transnational Corporations Review, 1-14.

Stiglitz, J. E. (1972). Some aspects of the pure theory of corporate finance: bankruptcies and take-overs. The Bell Journal of economics and management Science, 458-482.

Tarus, D. K., \& Aime, F. (2014). Board demographic diversity, firm performance and strategic change. Management Research Review.

Tarus, D. K., \& Ayabei, E. (2016). Board composition and capital structure: evidence from Kenya. Management Research Review.

Teece, D. J. (2019). A capability theory of the firm: an economics and (strategic) management perspective. New Zealand Economic Papers, 53(1), 1-43.

Tejerina-Gaite, F. A., \& Fernández-Temprano, M. A. (2020). The influence of board experience on firm performance: does the director's role matter?. Journal of Management and Governance, 1-21.

Terjesen, S., Sealy, R., \& Singh, V. (2009). Women directors on corporate boards: A review and research agenda. Corporate governance: an international review, 17(3), 320-337.

Ting, I. W. K., Azizan, N. A. B., \& Kweh, Q. L. (2015). Upper echelon theory revisited: The relationship between CEO personal characteristics and financial leverage decision. Procedia-Social and Behavioral Sciences, 195(3), 686-694.

Titman, S. (1984). The effect of capital structure on a firm's liquidation decision. Journal of financial economics, 13(1), 137-151. 
Titman, S., \& Wessels, R. (1988). The determinants of capital structure choice. The Journal of finance, 43(1), 119.

Titman, S., \& Wessels, R. (1988). The determinants of capital structure choice. The Journal of finance, 43(1), 119.

Titman, S., \& Wessels, R. (1988). The determinants of capital structure choice. The Journal of finance, 43(1), 119.

Torchia, M., Calabro, A., Gabaldon, P., \& Kanadli, S. B. (2018). Women directors contribution to organizational innovation: A behavioral approach. Scandinavian Journal of Management, 34(2), 215-224.

Ujunwa, A. (2012). Board characteristics and the financial performance of Nigerian quoted firms. Corporate Governance: The international journal of business in society.

Walters, B. A., Kroll, M. J., \& Wright, P. (2007). CEO tenure, boards of directors, and acquisition performance. Journal of Business Research, 60(4), 331-338.

Walters, B. A., Kroll, M. J., \& Wright, P. (2007). CEO tenure, boards of directors, and acquisition performance. Journal of Business Research, 60(4), 331-338.

Wang, Y., \& Yin, S. (2018). CEO educational background and acquisition targets selection. Journal of Corporate Finance, 52, 238-259.

Waweru, N. M., \& Prot, N. P. (2018). Corporate governance compliance and accrual earnings management in eastern Africa. Managerial Auditing Journal.

Westphal, J. D. (1999). Collaboration in the boardroom: Behavioral and performance consequences of CEO-board social ties. Academy of management Journal, 42(1), 7-24.

Wiersema, M. F., \& Bantel, K. A. (1992). Top management team demography and corporate strategic change. Academy of Management journal, 35(1), 91-121.

Wodak, R., Kwon, W., \& Clarke, I. (2011). 'Getting people on board': Discursive leadership for consensus building in team meetings. Discourse \& Society, 22(5), 592-644.

$\mathrm{Xu}$, J. (2012). Profitability and capital structure: Evidence from import penetration. Journal of Financial Economics, 106(2), 427-446.

Yang, L., \& Wang, D. (2014). The impacts of top management team characteristics on entrepreneurial strategic orientation. Management Decision.

Zelechowski, D. D., \& Bilimoria, D. (2004). Characteristics of women and men corporate inside directors in the US. Corporate governance: an international review, 12(3), 337-342.

Zeng, S., \& Wang, L. (2015). CEO gender and corporate cash holdings. Are female CEOs more conservative?. Asia-Pacific Journal of Accounting \& Economics, 22(4), 449-474.

Zhang, D. (2019). Top management team characteristics and financial reporting quality. The Accounting Review, 94(5), 349-375.

Zona, F. (2016). Agency models in different stages of CEO tenure: The effects of stock options and board independence on R\&D investment. Research Policy, 45(2), 560-575.

Zwiebel, J. (1996). Dynamic capital structure under managerial entrenchment. The American economic review, $1197-1215$. 